\title{
KUALITAS MIKROBIOLOGI AIR TAHU YANG DIJUAL DI KOTA MAKASSAR BERDASARKAN NILAI MPN COLIFORM, COLIFORM FEKAL DAN JUMLAH KOLONI BAKTERI Escherichia Coli SEBAGAI MATERI PENYULUHAN MASYARAKAT
}

\author{
Evi Ristiana \\ Dosen Universitas Muhammadiyah Makassar \\ E-mail: eviristiana_nawir@yahoo.co.id
}

\begin{abstract}
Abstrak: Penelitian ini adalah deskriptif dengan pendekatan observasi yang bertujuan untuk mengetahui kualitas mikrobiologi dari air tahu yang dipasarkan di Makassar berdasarkan nilai MPN coliform, koliform fecal, dan nilai Escherichia coli. Metode yang digunakan untuk mengetahui kualitas mikrobiologi air tahu adalah metode MPN yang terdiri dari uji penduga, uji konfirmasi, dan uji pelengkap. Hasil penelitian ini menjadi bahan informasi bagi masyarakat melalui penyuluhan yang bertujuan untuk memberikan pemahaman kepada masyarakat tentang kebersihan dan kemanan air tahu yang dikonsumsi.
\end{abstract}

Kata Kunci: Kualitas Mikrobiologi, Air Tahu, MPN Coliform

\section{THE QUALITY OF MICROBIOLOGY WATER TOFU SOLD IN THE CITY MAKASSAR BASED ON VALUE MPN COLIFORM, COLIFORM FACAL AND THE NUMBER OF BACTERIA COLONIES Escherichia coli AS OF MATTER COUNSELING THE COMMUNITY}

\begin{abstract}
Research is descriptive observation with an approach aimed at ascertaining the quality of microbiology of water know who marketed in Makassar based on the mpn coliform, fecal coliform, and the Escherichia coli. Methods used to know the quality of microbiology water tofu is the method mpn, consisting of the suspect, confirmation, and appendages. The water quality tests microbiology know feasibility and the consumption of water know in Makassar is the result of this research was the information for the community through understanding that aims to give information to the public about cleanliness and safety water tofu consumed
\end{abstract}

Keywords: Quality Microbiology, Water Tofu, Mpn Coliform

Air tahu merupakan salah satu jenis minuman hasil olahan kedelai, yang banyak diminati masyarakat Makassar karena bernilai gizi tinggi. Minat masyarakat kota Makassar untuk mengkonsumsi air tahu yang semakin meningkat, pada kenyataannya tidak diimbangi dengan kesadaran para pengrajin air tahu untuk memberikan jaminan dan kelayakan 
konsumsi air tahu untuk para konsumennya. Sampai saat belum diketahui kualitas mikrobiologi air tahu yang dijual di kota Makassar.

Penelitian ini diharapkan dapat mengungkap tentang kualitas mikrobiologi air tahu yang banyak beredar di kota Makassar berdasarkan nilai MPN coliform, coliform fekal dan jumlah koloni bakteri Escherichia coli. Apabila kualitas mikrobiologi air tahu yang beredar di kota Makassar telah diketahui dan disosialisasikan kepada masyarakat. Para konsumen air tahu akan lebih berhati-hati dalam mengkonsumsi air tahu yang ada di kota Makassar. Selanjutnya pengrajin air tahu diharapkan berusaha meningkatkan kualitas air tahu yang diproduksinya. Apabila melalui hasil penelitian ini dapat diperoleh informasi tentang kualitas mikrobiologi air tahu sehingga dapat digunakan sebagai bahan materi penyuluhan masyarakat, maka akan memberi nilai tambah dalam upaya peningkatan sanitasi dan higienitas dalam pengolahan air tahu yang banyak dikonsumsi masyarakat di kota Makassar.

\section{METODE PENELITIAN}

Penelitian ini merupakan penelitian deskriptif observasional yang bertujuan untuk menguji kualitas Mikrobiologi air tahu yang dijual di kota Makassar berdasarkan nilai MPN coliform, coliform fecal dan jumlah koloni Escherichia coli air tahu yang berasal dari Industri Rumah Tangga dan Pabrik Air Tahu di kota Makassar. Data hasil penelitian ini akan digunakan untuk menentukan kelayakan konsumsi air tahu yang digunakan sebagai sampel dalam penelitian ini berdasarkan nilai MPN coliform, nilai MPN coliform fecal dan jumlah koloni bakteri Escherichia coli dengan merujuk pada ketentuan yang telah ditetapkan dan disetarakan dengan standar kualitas mikrobiologi susu kedelai menurut SNI 01-3719-1995.

Populasi dalam penelitian ini ialah seluruh produk air tahu yang berasal dari industri rumah tangga dan pabrik air tahu yang terdapat di kecamatan Makassar, kecamatan Mariso, kecamatan Rappocini, kecamatan Mamajang di kota Makassar. Sampel dalam penelitian ialah air tahu yang diambil dari masing-masing pengrajin air tahu dikota Makassar. Pengambilan sampel dibagi dalam 2 tahap pengambilan sampel, yakni penentuan sampel pengrajin air tahu dan pengambilan sampel air tahu.

Teknik analisis data yang digunakan ialah statistik deskriptif yang bertujuan untuk membandingkan kualitas Mikrobiologi air tahu berupa nilai MPN coliform, nilai MPN coliform fecal dan jumlah koloni bakteri Escherichia coli dari setiap lokasi pengambilan sampel air tahu yang berasal dari industri rumah tangga dan dari pabrik air tahu, sehingga analisis statistik yang digunakan ialah statistik komparasi dengan uji t pada taraf signifikansi 5\%. 


\section{HASIL DAN PEMBAHASAN}

Data kualitas mikrobiologi Air Tahu berdasarkan Nilai MPN coliform, coliform fekal, dan Jumlah koloni Escherichia coli, dianalisis secara deskriptif dengan membandingkan sampel dari industri rumah tangga dengan sampel dari Pabrik air tahu, kemudian akan dirujukkan pada Standar Nasional Indonesia (SNI) khususnya pada standar kualitas minuman susu kedelai dari Badan Pengawasan Obat dan Makanan (BPOM). Hasil analisis data disajikan dalam Tabel 4.3.1. berikut;

Tabel 1. Perbandingan Nilai MPN coliform, coliform fekal, dan Jumlah koloni Escherichia coli sampel air tahu dari Industri Rumah tangga dan dari Pabrik Air Tahu

\begin{tabular}{cccc}
\hline $\begin{array}{c}\text { Sampel } \\
\text { air tahu }\end{array}$ & $\begin{array}{c}\text { Nilai MPN coliform } \\
(\mathrm{sel} / \mathrm{ml} \text { sampel })\end{array}$ & $\begin{array}{c}\text { Nilai MPN coliform fekal } \\
(\mathrm{sel} / \mathrm{ml} \text { sampel })\end{array}$ & $\begin{array}{c}\text { Jumlah koloni Escherichia coli. } \\
(\text { sel/100ml sampel) }\end{array}$ \\
\hline IRT & $>2400$ & 1375 & 29 \\
PB & 104,75 & 77,25 & 4,75 \\
\hline
\end{tabular}

Keterangan: IRT $=$ Industri Rumah Tangga

$\mathrm{PB}=$ Pabrik Air Tahu

Perbandingan nilai MPN coliform, coliform fekal, dan Jumlah koloni bakteri Escherichia coli sampel air tahu antara industri rumah tangga dan pabrik air tahu dapat dilihat pada Gambar 1 berikut

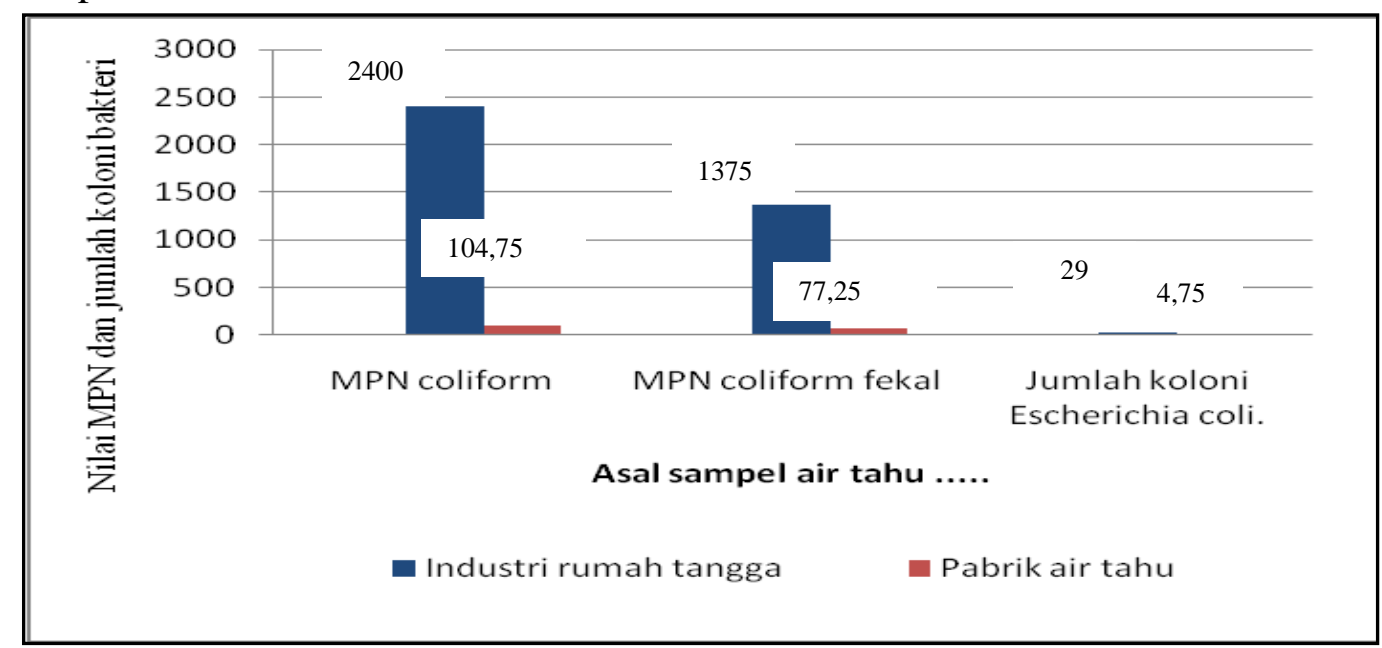

Gambar 1. Histogram perbandingan kualitas mikrobiologi air tahu pada Industri Rumah Tangga dan Pabrik Air Tahu.

Gambar 1. menunjukkan bahwa pada sampel air tahu yang berasal dari Industri Rumah Tangga dan Pabrik Air Tahu mempunyai perbedaan nilai MPN coliform. Setelah dilakukan uji penegasan juga diperoleh nilai MPN coliform fekal berbeda antara sampel air tahu dari industri rumah tangga dengan pabrik air tahu. Nilai MPN coliform sampel air tahu dari industri rumah tangga ialah $2400 \mathrm{sel} / \mathrm{ml}$ sampel, sedangkan nilai MPN coliform sampel pabrik air tahu ialah rata-rata 104,75 sel/ml sampel. Jadi nilai MPN coliform air tahu dari industri rumah tangga lebih tinggi jika dibandingkan dengan nilai MPN coliform air tahu dari pabrik air tahu. Nilai MPN coliform fekal dari industri rumah 
tangga ialah $1375 \mathrm{sel} / \mathrm{ml}$ sampel, sedangkan nilai MPN coliform fekal air tahu dari pabrik air tahu ialah rata-rata 77,25 sel/ml sampel. Jadi nilai MPN coliform fekal air tahu dari industri rumah tangga lebih tinggi jika dibandingkan dengan nilai MPN coliform fekal air tahu dari pabrik air tahu.

Berdasarkan hasil uji kepastian diperoleh data jumlah koloni Escherichia coli sampel air tahu yang berasal dari industri rumah tangga berbeda secara signifikan dengan jumlah koloni Escherichia coli sampel air tahu yang berasal dari Pabrik Air Tahu. Data pengujian kualitas mikrobiologi air tahu berdasarkan jumlah koloni Escherichia coli pada Industri Rumah Tangga dan Pabrik Air Tahu dianalisis dengan menggunakan uji beda-t dengan tingkat signifikansi 5\%. Hasil analisis data disajikan dalam Tabel 2.

Tabel 2. Hasil Perhitungan Uji t tidak berpasangan

\begin{tabular}{|c|c|c|}
\hline $\begin{array}{r}\text { Rerata jumlah koloni Escherichia coli dalam sampel air tahu } \\
\text { dari ... (koloni/ml sampel) }\end{array}$ & $\begin{array}{c}\text { Nilai signifikansi } \\
\text { (p-value) }\end{array}$ \\
\hline IRT & PB & $\mathrm{t}=4.386$ dan $\mathrm{p}=0.005$ \\
\hline $29 \pm$ SD 10.36 & $4.75 \pm$ SD 3.86 & \\
\hline
\end{tabular}

Keterangan: IRT = Industri Rumah Tangga

PB = Pabrik Air Tahu

$\mathrm{SD}=$ Standar deviasi

Tabel 2. membuktikan bahwa ada perbedaan yang signifikan jumlah koloni Escherichia coli antara industri rumah tangga dan pabrik air tahu dengan nilai signifikansi (p) sebesar 0.005 ( $<$ 00.05). Jumlah koloni Escherichia coli dalam sampel air tahu dari industri rumah tangga sebesar $29 \mathrm{koloni} / \mathrm{ml}$ sampel, sedangkan pabrik air tahu sebesar $4.75 \mathrm{koloni} / \mathrm{ml}$ sampel. Oleh karena perbedaan jumlah koloni Escherichia coli dalam sampel air tahu dari industri rumah tangga dan dari pabrik air tahu cukup besar, maka menyebabkan hasil pengujian secara statistik berbeda secara signifikan. Selanjutnya, jumlah koloni Escherichia coli dalam sampel air tahu dari industri rumah tangga dan dari pabrik air tahu juga dapat digambarkan pada Gambar 2. berikut ini;

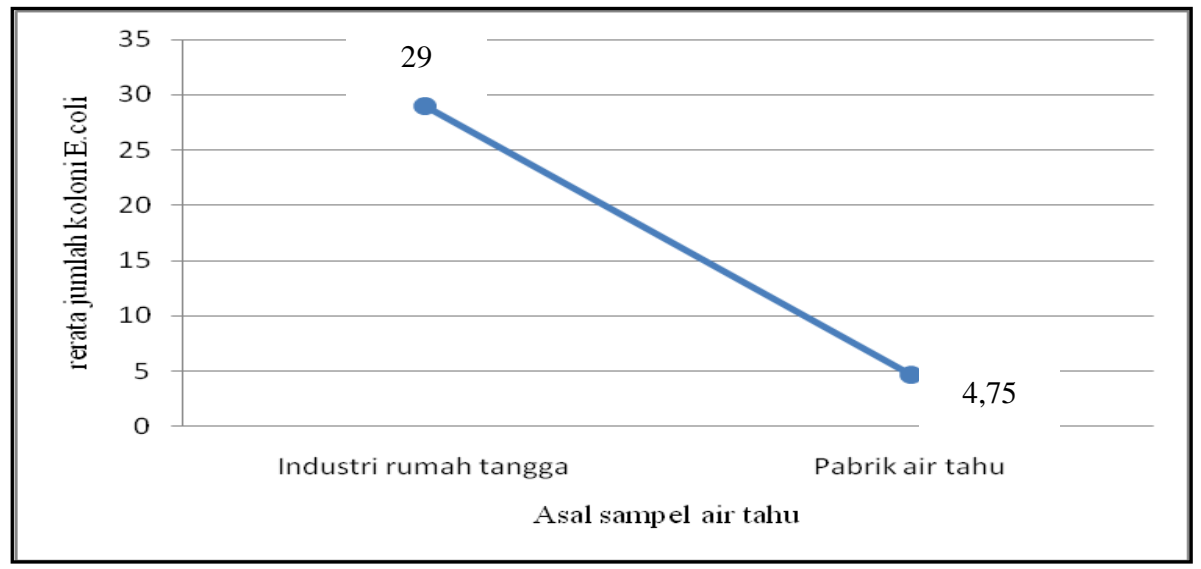

Gambar 2. Grafik Perbedaan Jumlah koloni Escherichia coli dari industri rumah tangga (IRT) dan dari pabrik air tahu (PB) 
Melalui Gambar 2 tersebut dapat diketahui bahwa rata-rata Jumlah koloni Escherichia coli pada Industri Rumah Tangga hasil pengujian secara statistik berbeda signifikan dengan sampel Pabrik air tahu.

Persyaratan dalam peraturan Internasional (WHO dan APHA) dan peraturan Menteri Kesehatan Republik Indonesia No 173/Men.Kes/Per/VIII/77 melalui badan POM menjelaskan bahwa kualitas mikrobiologi ialah salah satu parameter kualitas makanan dan minuman yang layak untuk dikonsumsi. Adapun Keputusan Menteri Kesehatan No: 907/MENKES/SK/VII/2002 mengatur bahwa salah satu indikator yang dipersyaratkan untuk minuman yang aman untuk dikonsumsi ialah tidak terkontaminasi oleh bakteri Coliform dan Coliform fekal. Kontaminasi minuman oleh bakteri tersebut dapat diketahui dengan melalui pengujian kualitas mikrobiologi dengan metode MPN (Suriawiria, 2008).

Kemungkinan faktor penyebab kontaminasi mikroba ke dalam air tahu hasil olahan industri rumah tangga ialah faktor pengolahan yang kurang memperhatikan higienitas dan sanitasi lingkungan. Penguasaan pengetahuan tentang cemaran mikroba dalam proses pengolahan air tahu pada masyarakat pengrajin air tahu dari industri rumah tangga masih rendah, karena latar belakang pengetahuan pengrajin air tahu yang diperoleh tidak bersangkut paut dengan cemaran mikroba ke dalam makanan-minuman hasil olahannya. Porwanto (1990), mengemukakan bahwa pemahaman terhadap suatu objek rendah akibat rendahnya motivasi belajar terhadap objek tersebut. Pemahaman pengrajin air tahu industri rumah tangga terhadap kebersihan pengolahan air tahu dapat dikatakan sebatas pada pengetahuan mengenal dan belum sampai pada tingkat pengetahuan atau pemahaman yang lebih tinggi. Hal ini terlihat dalam proses pengolahan air tahu yang tidak memiliki standar higienis dan sanitasi dalam proses pengolahannya. Penyakit diare merupakan salah satu penyakit yang sering terjadi akibat kurang diperhatikannya kebersihan pengolahan makanan. Menurut Dharma (2008), penyebab makanan tercemar bakteri penyebab penyakit diare dipastikan dari produsen yang kurang memperhatikan higiene dan sanitasi dalam pengolahan makanan.

Rendahnya tingkat pendidikan akan sangat mempengaruhi terhadap proses pengolahan air tahu yang aman dikonsumsi sehingga perlu diupayakan usaha-usaha pemecahan dalam peningkatan pengetahuan, sikap dan peran serta masyarakat yang masih rendah tingkat pendidikannya. Perlu secara dini dimasyarakatkan pengetahuan mengenai higienitas dan sanitasi sehingga akan membentuk sikap dan perilaku yang lebih baik dikemudian hari. Penelitian ini telah berhasil mengungkapkan tentang kualitas mikrobiologi air tahu berdasarkan nilai MPN coliform, nilai MPN coliform fekal, dan jumlah koloni bakteri Escherichia coli. Terbukti bahwa kualitas mikrobiologi air tahu yang digunakan dalam penelitian ini tidak memenuhi standar yang ditetapkan oleh BPOM Indonesia yang disesuaikan dengan standar susu kedelai SNI 01-3719-1995. Hasil penelitian ini dapat dijadikan sebagai sumber belajar dalam bentuk materi penyuluhan 
masyarakat yang merupakan media pembelajaran masyarakat. Materi penyuluhan membahas tentang manfaat air tahu yang bernilai gizi tinggi, namun demikian apabila air tahu tercemar oleh mikroorganisme dapat menyebabkan penurunan mutu. Berbagai jenis mikroorganisme penyebab penyakit akan tumbuh subur karena faktor sanitasi dalam pengolahan air tahu yang kurang diperhatikan. Penyuluhan masyarakat merupakan salah satu upaya pemberdayaan masyarakat pengrajin air tahu dalam memproduksi air tahu yang sehat dan higienis.

Uraian materi penyuluhan yang diungkapkan merupakan materi yang berhubungan langsung dengan proses pengolahan air tahu yang sesuai dengan standar sanitasi dan higiene dalam pengolahan pangan yang baik. Bahan materi penyuluhan akan membantu dalam upaya peningkatan kualitas dan sanitasi dalam pengolahan makanan yang banyak dikonsumsi masyarakat di kota Makassar.

\section{KESIMPULAN}

1. Nilai MPN coliform air tahu yang berasal dari industri rumah tangga ialah $2400 \mathrm{sel} / \mathrm{ml}$ sampel.

2. Nilai MPN coliform fekal air tahu yang berasal dari industri rumah tangga ialah 1375 $\mathrm{sel} / \mathrm{ml}$ sampel.

3. Jumlah koloni Escherichia coli di dalam air tahu yang berasal dari industri rumah tangga ialah $29 \mathrm{koloni} / \mathrm{ml}$ sampel.

4. Nilai MPN coliform air tahu yang berasal dari Pabrik air tahu ialah $104,75 \mathrm{sel} / \mathrm{ml}$ sampel.

5. Nilai MPN coliform fekal air tahu yang berasal dari Pabrik air tahu ialah $77 \mathrm{sel} / \mathrm{ml}$ sampel.

6. Jumlah koloni Escherichia coli di dalam air tahu yang berasal dari pabrik air tahu ialah rata-rata $4,75 \mathrm{koloni} / \mathrm{ml}$ sampel.

7. Tidak ada perbedaan kualitas mikrobiologi air tahu dari industri rumah tangga dan pabrik air tahu; sampel air tahu dari kedua macam tempat tersebut, tidak layak dikonsumsi ditinjau berdasarkan ketentuan yang telah ditetapkan oleh BPOM berdasarkan SNI 01-3719-1995. Namun demikian bila ditinjau berdasarkan nilai MPN coliform, nilai MPN coliform fekal, dan jumlah koloni bakteri Escherichia coli terbukti bahwa ada perbedaan nilai. Nilai MPN coliform, nilai MPN coliform fekal, dan jumlah koloni bakteri Escherichia coli dalam air tahu dari pabrik air tahu lebih rendah bila dibandingkan dengan air tahu dari industri rumah tangga.

8. Hasil penelitian ini dapat diaplikasikan didalam bidang pendidikan, dalam bentuk materi penyuluhan bagi masyarakat pengrajin air tahu yang berisi tentang manfaat air tahu, proses dalam pengolahan air tahu yang higienis dan memadai, serta syarat-syarat sanitasi yang harus dipenuhi agar diperoleh produk air tahu yang aman dan layak dikonsumsi. 


\section{SARAN}

1. Bagi Dinas Kesehatan dan BPOM Kota Makassar perlu dilakukan penyuluhan kepada masyarakat pengrajin air tahu mengenai sanitasi dan higienitas dalam pengolahan air tahu melalui kegiatan penyuluhan, agar masyarakat pengrajin lebih memahami bahwa selain mempunyai rasa enak dan bergizi, pengolahan air tahu juga harus memenuhi syarat-syarat sanitasi dan harus higienis pula dalam pengolahannya.

2. Bagi Pemerintah Daerah Kota Makassar, diharapkan agar segera membuat standar kualitas, standar sanitasi dan higienitas dalam pengolahan air tahu serta persyaratan pengolahan air tahu, khususnya yang diberlakukan di Kota Makassar.

3. Bagi para peneliti lain yang sebidang disarankan agar meneliti kualitas mikrobiologi berbagai macam makanan dan minuman olahan yang banyak dikonsumsi oleh masyarakat di kota Makassar dengan menambahkan penilaian organoleptik, kualitas fisik, dan kualitas kimia.

\section{DAFTAR PUSTAKA}

Alaerts, G., dan Sri Sumestri Santika. 1987. Metode Penelitian Air. Usaha Nasional. Surabaya.

Ali, A. dan Yusminah Hala. 2005. Mikrobiologi Dasar. Universitas Negeri Makassar. Makassar.

Arikunto, Suharsimi. 2006. Prosedur Penelitian (Suatu Pendekatan Praktek). Rineka Cipta. Jakarta.

Badan POM. 2003. MUTU PANGAN. Deputi Bidang Pengawasan Keamanan Pangan Dan Bahan Berbahaya. Direktorat Surveilan dan Penyuluhan Keamanan Pangan. Badan Pengawas Obat dan Makanan. Jakarta.

Badan POM. 2003. MIKROBIOLOGI PANGAN. Deputi Bidang Pengawasan Keamanan Pangan Dan Bahan Berbahaya. Direktorat Surveilan dan Penyuluhan Keamanan Pangan. Badan Pengawas Obat dan Makanan. Jakarta.

Badan POM. 2003. HIGIENE DAN SANITASI PENGOLAHAN PANGAN. Deputi Bidang Pengawasan Keamanan Pangan Dan Bahan Berbahaya. Direktorat Survei dan Penyuluhan Keamanan Pangan. Badan Pengawas Obat dan Makanan. Jakarta.

BPPN. 2007. Profil Makassar. http://ciptakarya.pu.go.id/profil/profil/timur/sulsel/makassar.pdf. diakses 1 agustus 2009.

Buckle, Edward, Fleet, Wootton. 1987. Ilmu Pangan; Penerjemah Hari Purnomo, Adiono. Penerbit Universitas Indonesia. Jakarta.

Chandra, Budiman. 2007. Pengantar Kesehatan Lingkungan. Jakarta. EGC Penerbit Buku Kedokteran.

Fardiaz S. 1989. Mikrobiologi Pangan. Pusat Pusat Antar Universitas. Institut Pertanian Bogor. Bogor. 
Fardiaz, Srikandi. 1992. MIKROBIOLOGI PANGAN 1. Kerja sama PAU Pangan dan Gizi IPB - PT Gramedia Pustaka Utama. Jakarta.

Fardiaz, Srikandi. 1993. ANALISIS MIKROBIOLOGI PANGAN. Jakarta. PT RajaGrafindo Persada.

Fathonah, Siti. 2005. Higiene dan Sanitasi Makanan. Buku Ilmiah. Fakultas Teknik, Universitas Negeri Semarang. Semarang.

Fathoni Subkhan. 2008. Panduan Usaha Susu Kedelai Bagi KSM Ekonomi, Modul: Seri Peluang Usaha Susu Kedelai. Program Nasional Pemberdayaan Masyarakat (PNPM) Mandiri. Jepara.

Furchan, Arief. 1982. PENGANTAR PENELITIAN DALAM PENDIDIKAN. Usaha Nasional. Surabaya.

Hadioetomo, Ratna Siri. 1990. MIKROBIOLOGI DASAR LABORATORIUM: Teknik dan Prosedur Dasar Laboratorium. Gramedia. Jakarta.

Haffel. 2002. Kajian Tentang Pengetahuan Dan Sikap Masyarakat Dalam Pelestarian Kepiting Kenari (Bigrus Latro) Di Kecamatan Kayoa Kabupaten Maluku Utara. Tesis tidak diterbitkan. Pogram Pascasarjana Universitas Negeri Malang. Malang

Hastuti, Utami Sri. 2007. Petunjuk Praktik Mikrobiologi. Program Pascasarjana. Universitas Negeri Malang. Malang

Harianto. 2004. Penyuluhan Penggunaan Oralit Untuk Menanggulangi Diare di Masyarakat. FMIPA Universitas Indonesia. Majalah Ilmu Kefarmasian. Vol.1, No.1, 27-33. Jakarta.

Hermana. 1985. Pengolahan Kedelai Menjadi Berbagai Bahan Makanan. Puslitbang Gizi dan Pangan. Jakarta.

Hujjatusnaini. 2009. Kajian Tentang Kualitas Mikrobiologi Berdasarkan Nilai MPN Coliform, dan Total Koloni E.coli, Kualitas Fisik dan Kualitas Kimia Air Minum Isi Ulang di Kota Palangkaraya Sebagai Bahan Penunjang Praktikum Mikrobiologi. Tesis tidak diterbitkan. Program Pascasarjana Universitas Negeri Malang. Malang.

Ibrahim, 2002. Pengembangan Perangkat Pembelajaran. Jakarta: Direktorat Pendidikan Lanjutan Pertama. Direktoran Jenderal Pendidikan Dasar dan Menengah. Departemen Pendidikan Nasional.

Iffati. F. N. 2003. Hubungan Tingkat Pengetahuan Mengenai Higiene Sanitasi Dan Praktik Penjamah Makanan Dengan Kualitas Bakteriologis Pada Nasi Rames (Studi Warung Makan Terminal Tidar Kota Magelang, (Online),(http://magi.undip.ac.id/penelitian/31-versi-indonesia/125-hubunganfaktor-sosial-ekonomi-higiene-sanitasi-lingkungan-tingkat konsumsi-dankejadian-infeksi-dengan-status-gizi-anak-usia-2-5-tahun-di-kabupatensemarang-tahun-2003?format=pdf, diakses 25 Juni 2009) 
Irianto. 2007. MIKROBIOLOGI :Menguak Dunia Mikroorganisme. Yramawidya. Bandung

Indriyati, P. 12 November 1983. Pengolahan Susu dari Kedelai. Majalah Pertanian; Vol.18

Jasin, M. 1992. Zoologi Invertebrata. Sinar Wijaya. Surabaya.

Jumadi. 2009. Pengkajian Teknologi Pengolahan Susu Kedelai. Buletin Teknik Pertanian. Vol. 14 No.1, 34-36. Malang

Kusbiantoro, B. 1993. Sifat Fisikokimia dan Karakteristik Protein Kedelai (Glycine Mass

(L) Merril) dalam Hubungannya dengan Mutu Tahu yang Dihasilkan. Tesis tidak diterbitkan. Program Pasca Sarjana IPB. Bogor.

Mukhtaridi, 2008. Pembuatan Susu Kedelai. Fakultas Farmasi. Universitas Padjadjaran.

Mar'at. 1982. Sikap Manusia Perubahan, serta Pengukuran. Fakultas Psikologi. Universitas Padjajaran Bandung. Ghalia Indonesia. Jakarta.

Marietta. 2008. EMBA (online). http://www.marietta.edu. Diakses 13 mei 2008

Nabila. 2009. Air Tahu (online). http://www.unsri.ac.id/blog/nabila/inilah-hidup/susukedelai/mrdetail/1026. diakses 27 agustus 2009

Niningsih, Allina Setia. 2005. Pengaruh Konsentrasi Inokulum, Jenis Inokulum, dan Kultivar Kedelai Terhadap Warna, Aroma, Rasa, Kandungan Protein, dan Asam Total Soyghurt. Tesis Tidak diterbitkan. Program Pascasarjana Universitas Negeri Malang. Malang.

Notoatmodjo S. 1986. Komponen Pendidikan Pada Penyuluhan Kesehatan Masyarakat. FKM UI. Badan Penerbit Kesehatan Masyarakat. Jakarta

Notoatmodjo S. 1993. Pengantar Pendidikan Kesehatan dan Ilmu Perilaku Kesehatan, Edisi 1. Andy Offset. Yogyakarta.

Pelczar dan Chan. 2005. Dasar-Dasar Mikrobiologi 1 penerjemah: Ratna S. Hadioetomo dkk. Penerbit Universitas Indonesia (UI-Press). Jakarta.

Radiyati Tri et al. 1992. Pengelolaan Kedelai. BPTTG Puslitbang Fisika Terapan LIPI. Hal-15. Subang.

Retno. G. 2009. Profil Konsumen Obat Tradisional Terhadap Ketanggapan Akan

Adanya Efek Samping Obat Tradisional, (Online), (http://apotekputer. com/ma

- apotekputer.com, diakses 25 Juni 2009).

Santoso, Hyeronymus Budi. 1995. Susu \& Yoghurt Kedelai. Yogyakarta. Kanisius.

Saraswati. 1986. Susu Kedelai. Bharat Karya Aksara. Jakarta.

Sastrosupadi, Adji. 1999. RANCANGAN PERCOBAAN PRAKTIS BIDANG PERTANIAN. Kanisius. Yogyakarta.

Singarimbun, Masri, Sofian Effendi. 2006. METODE PENELITIAN SURVAI edisi revisi. Lembaga Penelitian, Pendidikan, dan Penerangan Ekonomi, dan Sosial (LP3ES). Jakarta. 
Supardi, Imam dan Sukamto. 1999. Mikrobiologi dalam Pengolahan dan Keamanan Pangan. Alumni. Bandung.

Sugiyono. 2007. STATISTIKA untuk PENELITIAN. Alfabeta. Bandung.

Sugiyono. 2008. METODE PENELITIAN KUANTITATIF, KUALITATIF DAN R\&D. Alfabeta. Bandung.

Suriwiria. 2005. Mikrobiologi Air dan Dasar Pengolahan Buangan Secara Biologis. Tim Alumni. Bandung 